Review Artícle

\title{
Use of Herbal Preparations in Dry Cow Management against Sub Clinical Mastitis - An Alternative Approach
}

\author{
Tripti Kumari*, Champak Bhakat and Rajeev Kumar Choudhary
}

ICAR- Eastern Regional Station, National Dairy Research Institute, Kalyani, West Bengal, INDIA

*Corresponding author: triptilpm@gmail.com

\begin{tabular}{|ll} 
Rec. Date: & Feb 15, 2018 05:37 \\
Accept Date: & Feb 19, 2019 08:23 \\
DOI & $\underline{10.5455 / \text { ijlr.20180215053754 }}$ \\
\hline
\end{tabular}

\section{Abstract}

Sub clinical mastitis is the most prevalent disease in the dairy cows due to managemental problem which causes huge economic losses to the farmers. Animals are susceptible to new intramammary infections both at the beginning and end of dry period. Dry cow management is an important tool to control sub clinical mastitis. Managing dry cows by use of an antibiotics causes a detrimental effect on both human and animal health. So, at present herbs are gaining importance for treating the cow against mastitis. Use of herbal preparations by intramammary route, teat sealants either internally or externally or combination therapy can help in the reduction of new intramammary infections as well as cure existing infection from the udder of cow. Hence, use of herbal preparations to control sub clinical mastitis in dairy cow can be an innovative and alternative approach in cattle health care practices.

Key words: Sub clinical mastitis, Dry cow management, Intramammary, Herbal preparations

How to cite: Kumari, T., Bhakat, C., \& Choudhary, R. (2019). Use of Herbal Preparations in Dry Cow Management against Sub Clinical Mastitis - An Alternative Approach. International Journal of Livestock Research, 9(3), 21-27. doi: 10.5455/ijlr.20180215053754

\section{Introduction}

Sub clinical mastitis in dairy cow is a major and silent problem causes higher economic losses to the farmers. It is one major reason for low yield and poor quality milk and ranks first among the diseases that causes substantial loss to owners. Mastitis is defined as inflammation of parenchyma of mammary glands and is characterized by physical, chemical and usually bacteriological changes in milk and pathological changes in glandular tissues (Radostitis et al., 2000). It is a global problem as it adversely affects on animal health, quality of milk and economics of milk production and every country including developed ones suffers huge financial losses related to culling, decreased production, decreased fecundity, and treatment costs (Seegers et al., 2003). Since it is a complex disease with multiple causal factors associated with various management practices of farm especially when the cows are dry. Management of dry animals are 
an important practices of farm because the dry period offers a valuable opportunity to improve udder health, while cows are not lactating. On the other hand, the beginning (initial 2-3 weeks) and the final 2-3 weeks of gestation period is very vulnerable to new infections. Today, dry cow management is an integral part of mastitis control programme. The use of antimicrobials in dairy animals is a widely accepted practice of farm management system but its use for a long period of time causes severe health hazard to human. So, at present use of herbal preparations are gaining importances in cattle healthcare practices. Although various herbal preparations used intramammary or topical have shown good effect in controlling sub clinical mastitis cases. Therefore, dry cow management through herbal preparations can provide an alternative approach in dairy herds against sub clinical mastitis.

\section{Dry Cow Management}

The udder of the dairy cow requires a non-lactating or rest period, prior to calving in order to optimize milk production in the subsequent lactations. This phase of lactation cycle commonly referred to as dry period. A 45-60 days dry period is recommended. Milk production will be $25-30 \%$ less in the next lactation if a dry period is not allowed. The non-lactating period is related to the dynamics of intramammary infection (IMI) within a dairy herd. Existing infections from the previous lactation as well as new infections established during the dry period contribute markedly to the increasing number of infected quarters that occur with each successive lactation. This relationship of dry period with the level of mastitis in the dairy cow resulted in the development of dry cow management as a necessary component of sub clinical mastitis control to both eliminate existing infections and prevent new ones (Nickerson, 2010). Prevalence of mastitis among quarters at dry-off time generally may range between 10-30\%, likewise new infections in quarters not treated at this time may also range between 10-30\%. Dry cow therapy is 70-90\% effective in curing existing cases of mastitis and 50\% effective in preventing new infection (Nickerson, 2015)

\section{Disadvantage of Antibiotic/Antimicrobial Use}

Antibiotics have been in use in the treatment of bovine mastitis since decades; however, their use is associated with cost issues and human health concern. The use of antibiomicrobials for a long period of time has triggered the development of multidrug resistance strains of several bacterial species. This results in the use of higher dose of antimicrobials, causing the danger of increasing amount of drug residues in milk that causes a potential biohazard (Chockalingam, 2007).

\section{Advantage of Herbal Preparations}

Herbs are considered as God's gift to human beings in form of natural medicines. It can be easily available, prepared and of low cost (Chakraborty and Pal, 2012). Use of herbal drugs does not generally carry any disadvantages as antibiotics. Many plants/herbs have been evaluated in the treatment of bovine mastitis 
with additional property of immunomodulation in affected mammary gland (Bhatt, 2015). So, the use of medicinal plants in the treatment of diseases as well as increasing the productivity of high yielding animal like cattle has generated renewed interest in recent times and herbal preparations are increasingly being used in cattle healthcare practices (Wanzala et al., 2005; Gonzalez et al., 2011).

Dry cow management by herbal preparations leads to economic management for controlling sub clinical mastitis. Thus the use of medicinal plants (herbal preparations) may present a cheaper and sustainable alternatives to synthetic medicines (Chakraborty and Pal, 2012).

\section{Use of Intramammary Herbal Preparations}

Medicines that are extracted from the herbs are used as intramammary infusion in the dry animals. They are "natural" and usually safe and have clinical and economical value in treating resistant bacteria (Buhner, 2014). The herbal treatment tested for dairy cows in the dry period is found to be an alternative to antibiotics (Mullen et al., 2013). Baskaran et al. (2009) demonstrated that plant derived antimicrobials have shown promise in vitro as treatments for mastitis; trans-cinnamaldehyde (from cinnamon bark), thymol (from oregano oil) and eugenol (from clove oil) were shown to be effective in milk cultures versus several major mastitis pathogens. Cinnamon and clove oils have shown antibacterial and antifungal activity for bovine mastitis (Choi et al., 2012).

Neem oil is effective against udder infections. The bark, seeds, leaves and roots of neem are used as an insect repellant. Livestock insects such as horn flies, flow flies and biting flies are controlled traditionally using neem (Ogbueniu et al., 2011). Neem oil are effective against E. coli and mastitis (Ogbueniu, 2008). Neem (Azadiracta indica) can be used as anti-inflammatory and antibacterial drug and can be an alternate therapy against bovine mastitis. Gram positive bacteria especially Staphylococcus aureus is sensitive to essential oil derived from turmeric (Gupta et al., 2015). Nigella sativa extract has potential as a therapeutic agent for Staphylococcus aureus infection causing sub clinical mastitis of dairy cows and may contribute to the cow's recovery from mastitis (Azadi et al., 2011). It has been reported that milk somatic cell count of the quarters infected with Staphylococus aureus decreased after injection of Nigella sativa extract in Holstein cows (Azadi and Farzaneh, 2010). Herbal preparation had a positive effect on the time to recovery from mastitis and increased the rate of bactereological cure together with improving the reduction of somatic cell count in dairy cows Pinedo et al. (2013). Mullen et al. (2014) reported that the herbal treatment tested did not negatively affect milk production or somatic cell count and were just as successful as conventional dry cow therapy in curing infections during the dry period. Cows treated with the herbal preparation at dry off had fewer new infections (35\%) than no treatment (49\%). Thyme oil, an ingredient of the herbal treatment, has significant antibacterial activity when cultured in milk. 


\section{Use of Teat Sealant}

Because of the growing concern about antibiotic overuse, there is increased interest in the use of intramammary teat sealants. This is a different approach to the prevention of intramammary infections during the dry period. The National Mastitis Council's Recommended Mastitis Control Program suggests using a teat sealant on dry cows exposed to a high level of environmental pathogens.

\section{Internal Teat Sealant}

Sealing the teat canal of cow after drying off for the prevention of new IMI acts as an internal teat sealant. It provides a non-antibiotic approach in protecting uninfected cows from environmental mastitis bacteria during the dry period. They are inert compounds that physically prevent bacteria from entering the udder through the teat end, an intervention that mimics the natural defense mechanism of a keratin plug, closing each teat canal at drying-off.

Woolford et al. (1998) reported that new intramammary infection (IMI) during the dry period was found to be less in the group of cows treated with teat sealant than untreated quarters (12/505 vs. 67/528). Williamson (2001) reported that new IMI during dry period was found less in teat sealant treated than untreated quarters in cows (37/659 vs. 74/662). Huxley et al. (2002) observed that new IMI during dry period was found to be less in teat sealant than antibiotic treated quarters (103/928 vs. 145/940). Berry and Hillerton (2002) has observed that new IMI during the dry period was found to be less in cows treated with teat sealant than in untreated cows (21/197 vs. 62/201). They have also reported that clinical mastitis during the dry period is less in cows treated with teat sealant than untreated cows (0/197 vs. 6/204). Protection from new IMI during dry period in cows was found to be more i.e., 89 among 105 quarters in novel teat sealant containing chlorhexidine than untreated group i.e., 6 among 28 quarters (Petroviski et al., 2011).

\section{External Teat Sealant}

Sealing the teat of uninfected cows externally at the end of lactation to prevent new IMI acts as external teat sealant. It provides an external physical barrier for the teat orifice during critical times in the dry period. Timms (1997) demonstrated a 46.8\% reduction in new IMI for cows that received a teat sealant. McDougall et al. (2008) reported that treatment with an external teat sealant reduced the prevalence of IMI compared with controls (12.1\% vs. $16.5 \%$,) or IMI caused by a major pathogen (3.8\% VS $6.0 \%$ respectively). Results showed a greater than $50 \%$ reduction in new dry period infections when using the external teat sealant, with no harmful effects on teat tissues or the teat end. This sealant appears to adhere to teat surfaces better if it is stored at $40^{\circ} \mathrm{F}\left(4.4^{\circ} \mathrm{C}\right)$ and applied cold so that it is in a more viscous state. In fact, in one study, use of the product under warm and humid conditions was believed to compromise efficacy; thus, climactic conditions may be responsible for conflicting results (Nickerson, 2010). 
The efficacy of an external teat sealant has been confirmed by Leslie (1999) and in subsequent trials by Hemling (2000) and Timms (2001). The teat sealant functions by preventing environmental organisms from entering the udder. Duration of adherence of the sealant to the teat, and protection of the teat orifice, are critical factors in the performance of the teat sealant. Timms (2001) has suggested that an external teat sealant might be an effective substitute for dry cow antibiotic therapy in the prevention of new dry period infections.

\section{Use of Combination Therapy (Intramammary Herbal Preparation + Teat Sealant)}

Various study on the use of intramammary herbal preparation along with teat sealant demonstrated a significant reduction in percentage of new dry period infections after experimental bacterial challenge. The seal remained in place in the teat canal and teat cistern for three to four weeks. Mullen et al. (2012) studied the effect of two herbal preparations (Phytomast herbal product and Cinnatube as herbal internal teat sealant) and found that their combination have better effect than in curing existing infections. It is possible that the two herbal treatments worked synergistically to eradicate bacterial presence.

\section{Conclusion}

Subclinical mastitis in dairy cows can be controlled during the dry period by proper management. It can be best achieved by the use of herbal preparations on the animals through intramammary route and external application. Therefore, it can be considered as an alternative approach and consider as a farmers friendly management practices for controlling subclinical mastitis in dairy cows.

\section{References}

1. Azadi, H.G. and Farzaneh, N. (2010). Comparison of two regimens of Nigella sativa extracts for treatment of subclinical mastitis caused by Staphylococcus aureus. American Journal of Applied Sciences, 7(9), 1210-1214.

2. Azadi, H.G., Farzaneh, N., Baghestani, Z., Mohamadi, A. and Shahri, A.M. (2011). Effect of intramammary injection of Nigella sativa on somatic cell count and Staphylococcus aureus count in Holstein Cows with $S$. aureus subclinical mastitis. American Journal of $\quad$ Animal and Veterinary Sciences, 6(1), 31-34.

3. Baskaran, S.A., Kazmer, G.W., Hinckley, L., Andrew, S.M. and Venkitanarayanan, K. (2009). Antibacterial effects of plant derived antimicrobials on major bacterial mastitis pathogens in vitro. Journal of Dairy Science, 92(4), 1423-1429. DOI.org/10.3168/jds.2008-1384.

4. Berry, E.A. and Hillerton, J.E. (2002). The effect of an intramammary teat seal on new intramammary infections. Journal of Dairy Science, 85, 2512-2520.

5. Bhatt, N. (2015). Herbs and herbal supplements, a novel approach in animal nutrition. Iranian Journal of Applied Animal Science, 5(3), 497-516.

6. Buhner, S.H. (2014). Herbal antibiotics: an effective defense against drug resistant 'Superbugs'. Mother Earth News.

7. Chakraborty, S. and Pal, S.K. (2012). Plants for cattle health: a review of ethnoveterinary herbs in veterinary health. Annals of Ayurvedic Medicine, 1(4), 144-150. 
8. Chockalingam, A., Zarlenga, D.S and Bennerman, D.D. (2007). Antimicrobial activity of bovine bactericidal permeability increasing protein derived peptides against gram-negative bacteria isolated from the milk of cows with clinical mastitis. American Journal of Veterinary Research, 68 (11), 11511159.

9. Choi J.Y., Damte, D., Lee, S.J. and Pork, S.C. (2012). Antimicrobial activity of Lemongrass and Oregano essential oil against standard antibiotic resistant Staphylococcus aureus and field isolates from chronic mastitic cows. International Journal of Phytomedicine, 4(1), 134- 139.

10. Gonzalez, J.A., Garcia-Barriuso, M. and Amich, F. (2011). Ethnoveterinary medicine in the Arribes del Duero, Western Spain. Veterinary Research Communications, 35(5), 283-310.

11. Gupta, A., Mahazan, S. and Sharma, R. (2015). Evaluation of antimicrobial activity of Curcuma longa rhizome extract against Staphylococcus aureus. Biotechechnology Reports. 6, 51-55. DOI: 10.1016/j.btre.2015.02.001.

12. Hemling, T., Henderson, M. (2000). IDF Symposium on immunology of ruminant mammary glands. p. 19.

13. Huxley, J.N., Green, M.J., Green, L.E. and Bradley, A.J. (2002). Evaluation of the efficacy of an internal teat sealer during the dry period. Journal of Dairy Science, 85(3): 551-561.

14. Leslie, K.E., Kelton, D.F. and Day, K.J. (1999). Milking management in Ontario dairy herds; National Mastitis Council Annual Meeting Proceedings, pp. 126-127.

15. Mcdougall S., Parker, K.I., Weir, A.M and Compton, E.W. (2008). Effect of application of an external teat sealant and or oral treatment with a monensin capsule pre-calving on the prevalence and incidence of subclinical and clinical mastitis in dairy heifers. New Zealand Veterinary Journal, 56(3), 120-129.

16. Mullen, K.A.E., Lyman, R., Washburn, S.P. and Anderson, K.L. (2012). Efficacy of two herbal remedies as alternative to antibiotics in dry cow therapy: preliminary microbiology results. College of Agriculture and Life Sciences Academics, Research, Extension.

17. Mullen, K.A.E., Sparks, L.G. Lyman, R.L., Washburn, S.P and Anderson, K.L. (2013). Comparisons of milk quality on North Carolina organic and conventional dairies. Journal of Dairy Science, 96(10). 6753-6762.

18. Mullen, K.A., Anderson, K.I. and Washburn, S.P. (2014). Effect of two herbal intramammary products on milk quantity and quality compared with conventional and no dry cow therapy. Journal of Dairy Science, 97(6), 3509-3522. DOI: 10.3168/jds.2013-7460.

19. Nickerson (2010). Importance of dry cow management in the control of mastitis. Dairy. USDA. National Institute for Agricultural Extension Project.

20. Nickerson (2015). Managing mastitis through proper dry-off procedures (B 1447). UGA Extension.

21. Ogbueniu, I.P. (2008). Physiological response of rabbits fed graded levels of neem (Azadirachta indica) leaf meal. M.Sc. Thesis., Federal University of Technology, Owerri.

22. Ogbueniu, I.P., Odomenam, V.U., Obikaonu, H.O., Opara, M.N., Emenalom, O.O., Uchegbu, M.C., Okoli, I.C., Esonu, B.O. and Loej, M.U. (2011). The growing importance of neem (Azadirachta indica) in agriculture industry, medicine and environment: A Review. Research Journal of Medicinal Plants, 5, 230-245. DOI: 10.3923/rjmp.2011.230.245.

23. Pinedo, P., Karreman, H., Bothe, H., Veliz, J. and Risco, C. (2013). Efficacy of a botanical preparation for the intramammary treatment of clinical mastitis on an organic dairy farm. The Canadian Veterinary Journal, 54(5), 479-484.

24. Petroviski R.R., Caldas, A.C., Williamson, N.B., Villalobos, N.L., Grinberg, A., Parkinson, T. J. and Tucker I.G. (2011). Efficacy of a novel internal dry period teat sealant containing $0.5 \%$ chlorhexidine against experimental challenge with Streptococcus uberis in dairy cattle. Journal of Dairy Science. 94 , 3366-3375.

25. Radostits, O.M., Gay, C.C., Blood, D.C. and Hinchcliff, K.W. (2000). Mastitis In: Veterinary Medicine, A Textbook of the Diseases of Cattle, Sheep, Pigs, Goats and Horses, Philadelphia, USA, W B Saunders Co., 9th edn., pp. 603-612. 
26. Seegers, H., Fourichon, C. and Beaudeau, F. (2003). Production effects related to mastitis and mastitis economics in dairy cattle herds, BioMed Central, Veterinary Research, 34(5), 475- 491.

27. Timms, L.L. (1997). Field trial evaluation of a persistent barrier teat dip for preventing mastitis during the dry period. Journal of Dairy Science, 80(1), 225.

28. Timms, L.L. (2001). Field trial evaluations of a novel persistent barrier teat dip for preventing mastitis during the dry period and as a potential substitute for dry cow antibiotic therapy. National Mastitis Council Annual Meeting Proceedings, pp. 262-263.

29. Wanzala, W., Zessin, K.H., Kyule, N M., Baumann, M.P.O., Mathias, E. and Hassanali, A. (2005). A ethnoveterinary medicine: a critical review of its evolution, perception, understanding and the way of foreward. Livestock Research on Rural Development, 17(11), 55-78.

30. Williamson, J. (2001). Strategies for protecting the teat at dry off. National Mastitis Council Annual Meeting Proceedings. pp. 88-94.

31. Woolford, N.W., Williamson, I.H., Day A.M. and Copeman P.J. (1998). The prophylactic effect of a teat sealer on bovine mastitis during the dry period and the following lactation. New Zealand Veterinary Journal, 46(1), 12-19. 